\title{
Management of Blood Transfusion in a Patient Carrying Anti-Rh18 Associated with the RHD*Weak D 4.2.2/RHCE*ceAR Haplotype
}

\author{
Costa SSM ${ }^{1,2}$, Chiba AK ${ }^{1}$, Cruz BR ${ }^{1}$, Fabron Jr A ${ }^{3}$, Chiattone $\mathrm{CS}^{2}$, Langhi Jr. $\mathrm{DM}^{2}$ and Bordin $\mathrm{JO}^{1 *}$ \\ ${ }^{1}$ Disciplina de Hematologia e Hemoterapia, Universidade Federal de São Paulo, SP, Brazil \\ ${ }^{2}$ Disciplina de Hematologia e Oncologia, Faculdade de Ciências Médicas da Santa Casa de São Paulo, Brazil \\ ${ }^{3}$ Faculdade de Medicina de Marilia, Marilia, Brazil
}

*Corresponding author: José O. Bordin, MD, Disciplina de Hematologia e Hemoterapia, Universidade Federal de São Paulo, Brazil, Tel: 55 11 55791550; E-mail: jobordin@unifesp.br

Received date: July 04, 2015, Accepted date: July 27, 2015, Publication date: July 31, 2015

Copyright: ( 2015 Costa SSM, et al. This is an open-access article distributed under the terms of the Creative Commons Attribution License, which permits unrestricted use, distribution, and reproduction in any medium, provided the original author and source are credited.

\begin{abstract}
The RH blood group system is the most polymorphic and immunogenic among blood groups. Variant Rh antigens have been found with high frequencies in African descendants persons. The DAR-ceAR haplotype results from the rearrangement of the RHCE gene with the internal sequences of the RHD gene that give rise to an altered Rh protein and may produce a clinically significant antibody. We report a case of anti-RH18 detected in a female patient with sickle cell trait. Serologic and molecular investigations were performed to identify RH variants from the propositus and her relatives. The results of genomic DNA analysis showed the propositus carrying the haplotype $\mathrm{RHD}^{*}$ weak D 4.2.2/RHCE ${ }^{*}$ ceAR, as well as her father and sister.
\end{abstract}

Keywords: $\mathrm{RHCE}^{\star} \mathrm{ce}$; Variant e antigen; $\mathrm{RHD}^{\star}$ weak D partial 4.0; Sickle cell trait patients

\section{Introduction}

Two highly homologous genes, RHD and RHCE, encode the Rh antigens. Many $\mathrm{RH}$ genes carry single nucleotide polymorphism (SNPs) change, or have rearrangements and exchanges between RHD and RHCE that result from gene conversion events. These alleles have mostly been described in non-white populations and give rise to an altered Rh protein.

Besides $\mathrm{Rh}_{\text {null }}$ and RhCE-depleted phenotypes, the RH:-18 phenotype (Hr-negative) has been described to be produced by 3 distinct variant RHCE alleles: ceEK carrying 48G>C (exon 1), $712 \mathrm{~A}>\mathrm{G}, 787 \mathrm{~A}>\mathrm{G}, 800 \mathrm{~T}>\mathrm{A}$ (exon 5); ceBI carrying $48 \mathrm{G}>\mathrm{C}$ (exon 1), $712 \mathrm{~A}>\mathrm{G}$ (exon 5), 818C $>\mathrm{T}$ (exon 6), 1132C $>\mathrm{G}$ (exon 8); and the ceAR carrying 48G $>C$ (exon1), 712A $>\mathrm{G}, 733 \mathrm{C}>\mathrm{G}, 787 \mathrm{~A}>\mathrm{G}, 800 \mathrm{~T}>\mathrm{A}$ (exon 5), and $916 \mathrm{~A}>\mathrm{G}$ (exon 6). Although individuals with these variant alleles type as e-positive they often make anti-e alloantibody (antiRH18) [1-3].

Anti-RH18 reacts with red blood cells (RBCs) carrying the common products of the RHCE gene, but react more strongly with Rhe-positive RBCs. When the anti-RH18 is adsorbed on Rhe-negative (DccEE) RBCs, the remaining reactivity shows anti-e or ce-like specificity and is named anti-RH19 (anti-hrs). The presence of anti-RH18 imposes the use of equivalent rare antigen-negative RBCs or deleted-Rh RBCs $\left(\mathrm{Rh}_{\text {null }}\right.$ or $\left.\mathrm{D}--\right)$ for transfusion [4-7].

\section{Case Report}

A serologic blood group typing was performed in a 24 -year-old Brazilian afro-descendant female patient candidate for a cholecystectomy. She was typed as blood group A, Dccee phenotype with weak $\mathrm{D}$. She presented a positive $\mathrm{RBC}$ antibody screening, negative auto-control and negative direct antiglobulin test (DAT). The identified antibody was anti-e.

She had a previous obstetric history of three pregnancies with spontaneous miscarriages and an ectopic pregnancy that required transfusion of one RBC unit, with no adverse reactions.

We performed a serologic and molecular investigation to identify $\mathrm{RH}$ variants on her husband and four relatives (the family pedigree is shown in Figure 1).

$\mathrm{Rh}$ phenotyping was performed according to the manufacturer's procedure by hemagglutination in gel cards (DiaMed, Latino América S.A., Brazil), using polyclonal antibodies against D, C, c, E and e. Rh D and e-antigen reactivity was further analyzed with selected monoclonal and polyclonal antibodies (DiaMed, Latino América S.A, Brazil; Fresenius-Kabi, Brazil; and Biotest, Dreieich, Germany).

Antibody detection and identification were performed by PEG/IAT (Fresenius Kabi, Brazil), by Liss-Coombs gel cards and papain-treated RBCs (DiaMed, Latino America, Brazil). The anti-e antibody was confirmed in the adsorption procedure, with three different $\mathrm{RBC}$ phenotypes, DccEE, DCCee and dccee. The serum adsorbed was tested with two RBC panels: nontreated RBCs on Liss-Coombs gel cards and papain-treated RBCs (DiaMed, Latino America). Antibody titration was performed in tubes with polyspecific anti-human globulin (Fresenius-Kabi, Brazil) and the result was expressed as the reciprocal of the highest dilution in which agglutination was detected.

The monocyte monolayer assay (MMA) was executed, as described previously, to verify the clinical significance of the anti-e antibody [8]. Five hundred monocytes were examined microscopically, and the number of monocytes with adherent or phagocytosed RBCs was counted. A significant positive result was defined by a $3 \%$ or greater reactivity. 
Citation: Costa SSM, Chiba AK, Cruz BR, Fabron Jr A, Chiattone CS, et al. (2015) Management of Blood Transfusion in a Patient Carrying AntiRh18 Associated with the RHD*Weak D 4.2.2/RHCE*ceAR Haplotype. J Blood Disord Transfus S4: S4-004. doi: 10.4172/2155-9864.1000S4-004

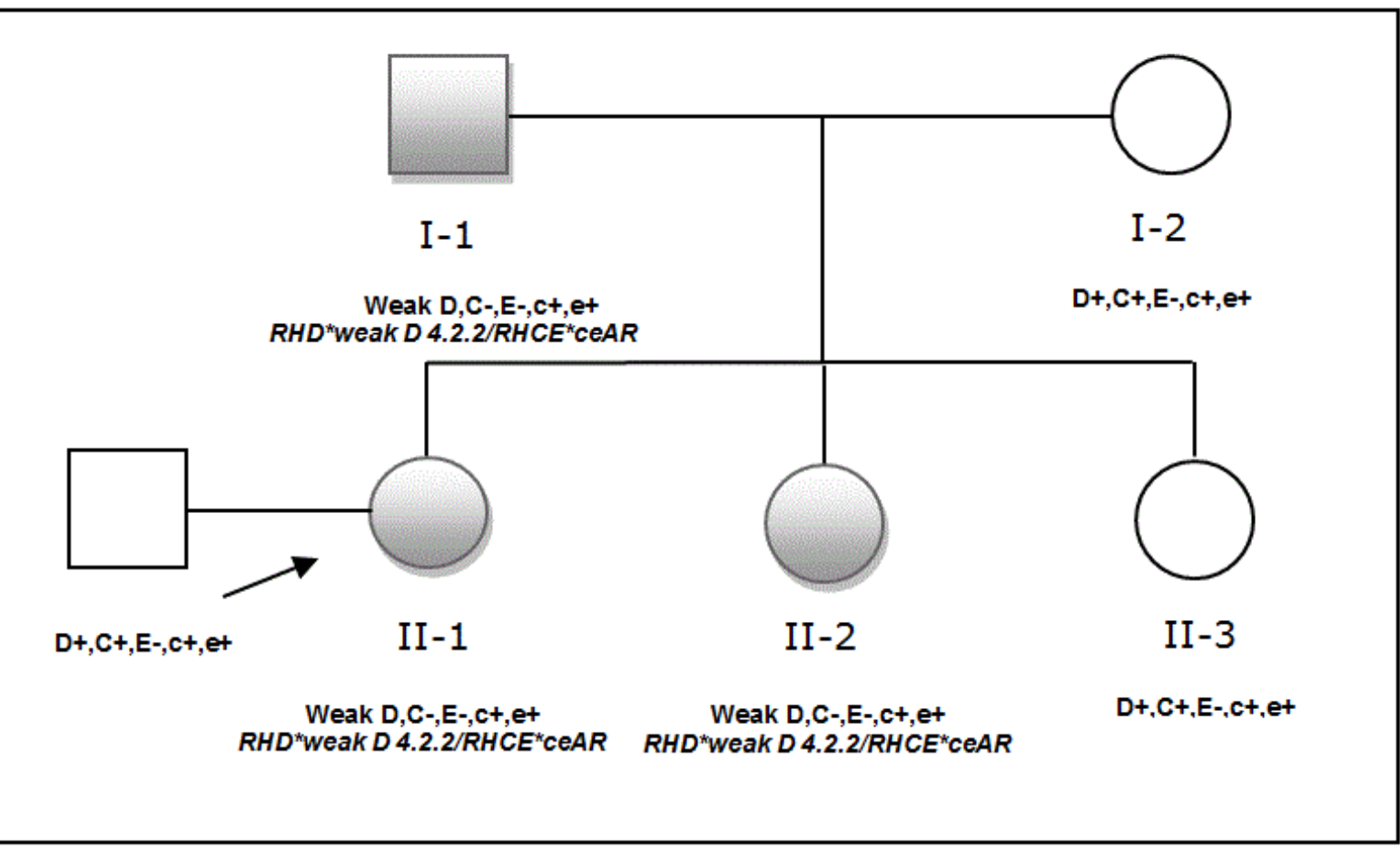

Figure 1: Family pedigree showing the patient (II-1, arrow) and her relatives.

The detection of abnormal hemoglobin was performed by gel electrophoresis hemoglobin. Genomic DNA was isolated from the whole blood using a commercial Kit (QIAamp DNA Blood mini kit, Qiagen, Hilden, Germany). Samples were sequenced in full length for the non-specific exon 3; RHD exons 4 to 5; RHCE exons 4 to 5; the RHCE exon 6; the RHD exon 6; and for the RHD exon 7, with the method described previously [1]. Nucleotide sequencing was performed with the DNA sequencing kit (Big Dye Terminator v1.1, applied Biosystems, Weiterstadt, Germany) and the genetic analyzer (ABI 3100, Applied Biosystems, Foster City, CA, USA).

The patient phenotype was weak $\mathrm{D}, \mathrm{C}-\mathrm{E}, \mathrm{E}-\mathrm{C}+, \mathrm{e}+$. The indirect antiglobulin test was reactive and an anti-e antibody was identified by three different screening panels with a titer of 64 . She presented a nonreactive auto-control test. In the adsorption technique with Rhenegative RBCs (DccEE), the retrieving antibody was anti-e-like that reacted with all normal Rhe-positive RBCs.

The patient, her father (I-1) and one sister (II-2) were found to be weak $\mathrm{D}$ by selected monoclonal and polyclonal anti-D tests, and all

\begin{tabular}{|l|l|l|l|l|l|l|}
\hline RBC & Phenotype & $\begin{array}{l}\text { Anti-D } \\
\text { Gel test } \\
\text { Polyclonal } \\
\text { (DiaMed) }\end{array}$ & $\begin{array}{l}\text { Anti-D } \\
\text { Tube/AGH } \\
\text { Polyclonal (DiaMed) }\end{array}$ & $\begin{array}{l}\text { Anti-D } \\
\text { Tube/AGH } \\
\text { Polyclonal } \\
\text { (Fresenius-Kabi) }\end{array}$ & $\begin{array}{l}\text { Anti-D } \\
\text { Gel test } \\
\text { Mube } \\
\text { ESD1 }\end{array}$ \\
\hline I-1 & Dccee & $3+$ & $1+/ 2+$ & $1+/ 2+$ & $4+$ \\
\hline I-2 & DCcee & $4+$ & $4+$ & $4+$ & $4+$ \\
\hline II-1 & Dccee & $3+$ & $1+/ 2+$ & $1+/ 2+$ & $4+$ & $4+$ \\
\hline
\end{tabular}

were phenotyped as Dccee (Table 1) showing normal reactivity with polyclonal and monoclonal anti-Rhe reagents.

Hemoglobin electrophoresis tests revealed that the patient, her father and sister were sickle cell trait carriers, as per the following results: patient (II- 1 ) $\mathrm{HbA} 1=55 \%, \mathrm{HbA} 2=2.8 \%, \mathrm{HbS}=41 \%, \mathrm{HbF}=1.2 \%$; father (I-1) $\mathrm{HbA} 1=58.5 \%, \mathrm{HbA} 2=1.4 \%, \mathrm{HbS}=37.7 \% \mathrm{HbF}=2.4 \%$; sister (II-2) $\mathrm{HbA} 1=57.4 \%, \mathrm{HbA} 2=2.5 \%, \mathrm{HbS}=38.6 \%, \mathrm{HbF}=1.5 \%$.

The sequence of RHD and RHCE transcripts were analyzed from four patient's relatives and from her husband. For I-1, II-1 and II-2 the transcripts showed the presence of the RHD Weak D type 4.2.2 (RHD DAR1.02) carrying nucleotide substitutions $602 \mathrm{C}>\mathrm{G}$ in exon 4 , $667 \mathrm{~T}>\mathrm{G}$ and $744 \mathrm{C}>\mathrm{T}$ in exon $5 ; 957 \mathrm{G}>\mathrm{A}$ and $1025 \mathrm{~T}>\mathrm{C}$ in exon 7; while on gene RHCE we found the RHCE ${ }^{*}$ ceAR (RHCE ${ }^{*}$ ce.04) carrying $48 \mathrm{G}>\mathrm{C}$ in exon $1,712 \mathrm{~A}>\mathrm{G}, 733 \mathrm{C}>\mathrm{G}, 787 \mathrm{~A}>\mathrm{G}$, and $800 \mathrm{~T}>\mathrm{A}$ in exon 5 and $916 \mathrm{~A}>\mathrm{G}$ in exon 6. 
Citation: Costa SSM, Chiba AK, Cruz BR, Fabron Jr A, Chiattone CS, et al. (2015) Management of Blood Transfusion in a Patient Carrying AntiRh18 Associated with the RHD*Weak D 4.2.2/RHCE*ceAR Haplotype. J Blood Disord Transfus S4: S4-004. doi: 10.4172/2155-9864.1000S4-004

Page 3 of 3

\begin{tabular}{|l|l|l|l|l|l|l|}
\hline $\mathrm{II}-2$ & Dccee & $3+$ & $1+/ 2+$ & $1+/ 2+$ & $4+$ & $3+$ \\
\hline $\mathrm{II}-3$ & DCcee & $4+$ & $4+$ & $4+$ & $4+$ & $4+$ \\
\hline
\end{tabular}

Table 1: Red blood cell (RBC) reactivity of patient and relatives with polyclonal and monoclonal anti-D reagents.

\section{Discussion}

The RHCE ${ }^{*}$ ce allele is present in the afro-descendant population, especially in sickle cell disease patients. Some of these alleles are associated with the loss of immunogenic epitopes, and there is a greater risk of alloimmunization when exposed to normal Rh antigens. Serological diagnosis of these alleles is difficult, especially when different combinations of altered alleles occur. Thus, the combination of molecular and serologic procedures have to be performed to detect these variants.

Anti-RH18 has been described as a clinically significant antibody causing fatal hemolytic transfusion [9]. The antibody was first discovered in the serum of a South African woman whose newborn had severe jaundice requiring exchange transfusion [9].

The frequency of the RHD variant DAR and the RHCE variant ceAR found in a group of 326 South-African black donors were $4.9 \%$ and $6.1 \%$, respectively, and the frequency of the haplotype DAR-ce-AR was 4.3\% [6]. Another study with Afro-Caribbean black sickle cell disease patients showed the presence of rare RHCE phenotypes including ceEK (1.4\%); ceAR (2.7\%); ceMO (2\%); (C)ces (7.5\%); ces(340) $(0.7 \%)$; and DAR-ceAR haplotype in two patients [1]. We have recently reported that the RHD ${ }^{*}$ weak D type 4.2 .2 is the most prevalent weak D phenotype in Brazilian blood donors and comprises approximately $0.25 \%$ of our population. It is expected that such individuals carry the RHD $^{*}$ weak D type 4.2.2/RHCE ${ }^{*}$ ceAR haplotype [10-12].

In this study we report a case of alloimmunization by anti-RH18 in a Brazilian afro-descendant woman who was exposed to the e antigen during her ectopic pregnancy, previous RBC blood transfusion, and/or due to the stillborn baby. Her husband presented the DCcee phenotype. Despite that the patient had suffered two spontaneous abortions, one ectopic pregnancy, and one stillborn baby, the reactivity index of $2 \%$ in the MMA test suggested that this antibody was clinically non-significant. Some authors suggest that the chemiluminescence test may be more valuable than the MMA for predicting hemolysis caused by RBC alloantibodies, especially if they are related to the Rh system $[10,11]$.

Besides the sickle cell trait, the family molecular analysis showed an inherited pattern of $\mathrm{RHD}^{*}$ weak D 4.2.2/RHCE ${ }^{*}$ ceAR associated with the Dccee phenotype in one other sister of the patient. RBC blood transfusions in patients carrying these rare phenotypes might become very challenging because the very low prevalence of compatible blood donors. We were fortunate to find family individuals with the same $\mathrm{RH}$ haplotype compatible to the rare alloantibody anti-RH 18 identified in the patient's serum, which allowed us to conduct a successful RBC transfusion before surgery.

\section{References}

1. Noizat-Pirenne F, Lee K, Pennec PY, Simon P, Kazup P, et al. (2002) Rare RHCE phenotypes in black individuals of Afro-Caribbean origin: identification and transfusion safety. Blood 100: 4223-4231.

2. Ouchari M, Polin H, Romdhane H, Abdelkefi S, Houissa B, et al. (2013) $\mathrm{RHD}^{*}$ weak partial 4.0 is associated with an altered $\mathrm{RHCE}^{*} \mathrm{ce}(48 \mathrm{C}, 105 \mathrm{~T}$, 733G, 744C, 1025T) allele in the Tunisian population. Transfus Med 23: 245-249.

3. Ba A,2, Beley $\mathrm{S} 3,2$, Chiaroni J3, et al. (2015) RH diversity in Mali: characterization of a new haplotype $\mathrm{RHD}^{\star} \mathrm{DIVa} / \mathrm{RHCE}^{\star} \mathrm{ceTI}(\mathrm{D} 2)$. Transfusion 55: 1423-1431.

4. Moores P (1994) Rh18 and hrS blood groups and antibodies. Vox Sang 66: 225-230.

5. Issitt PD (1994) Race-related red cell alloantibody problems. Br J Biomed Sci 51: 158-167.

6. Hemker MB, Ligthart PC, Berger L, van Rhenen DJ, van der Schoot CE, et al. (1999) DAR, a new RhD variant involving exons 4, 5, and 7, often in linkage with ceAR, a new Rhce variant frequently found in African blacks. Blood 94: 4337-4342.

7. Reid ME, Oyen R, Marsh WL (2000) Summary of the clinical significance of blood group alloantibodies. Semin Hematol 37: 197-216.

8. Nance SJ, Nelson JM, Horenstein J, Arndt PA, Platt LD, et al. (1989) Monocyte monolayer assay: an efficient noninvasive technique for predicting the severity of hemolytic disease of the newborn. Am J Clin Pathol 92: 89-92.

9. Shapiro M (1960) Serology and genetics of a new blood factor: hrs. J Forensic Med 7: 96-105.

10. Haspel RL, Vege S, Michelle D, Kaufman RM, Westhoff CM (2006) Serologic and molecular genetic management of a pregnancy complicated by anti-Rh18. Immunohematology 22: 132-135.

11. Fabron A Jr, Baleotti W Jr, de Mello AB, Chiba AK, Kuwano S, et al. (2004) Application of noninvasive phagocytic cellular assays using autologous monocytes to assess red cell alloantibodies in sickle cell patients. Transfus Apher Sci 31:29-35.

12. Cruz BR, Chiba AK, Moritz E, Bordin JO (2012) RHD alleles in Brazilian blood donors with weak D or D-negative phenotypes. Transfus Med 22: 84-89.
This article was originally published in a special issue, entitled: "Rh Blood Group System", Edited by Smita Mahapatra, SCB Medical College \& Hospital, India 